\title{
Stap saam met die sterwende sy laaste treë
}
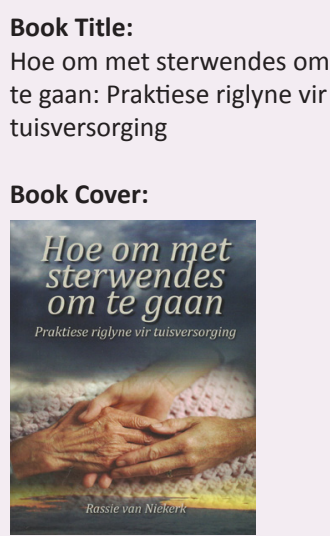

Author:

Rassie van Niekerk

ISBN:

978-0-86955-202-5

\section{Publisher:}

Potchefstroom Theological

Publications, 2012, R130.00

*Book price at time of review

Review Title:

Stap saam met die sterwende

sy laaste treë

\section{Reviewer:}

Cassie J.H. Venter ${ }^{1}$

\section{Affiliation:}

${ }^{1}$ Faculty of Theology, North-

West University, South Africa

Email:

casmar@lantic.net

Postal address:

c/o 3 Agapanthus Street,

Welgedacht 7530,

South Africa

How to cite this book review: Venter, C.J.H., 2013, 'Stap saam met die sterwende sy laaste treë', In die Skriflig/In Luce Verbi 47(1), Art. \#1127, 1 page. http://dx.doi.org/ 10.4102/ids.v47i1.1127

Read online:
Navorsing op die gebied van die pastorale begeleiding van sterwendes het sedert die sewentigerjare van die vorige eeu sterk toegeneem met Elizabeth Kübler-Ross in haar baanbrekerswerk, On death and dying (1969), op die voorpunt.

Die werk van Van Niekerk loop in dieselfde spore en lewer ' $n$ verdienstelike bydrae op die gebied van die Praktiese Teologie. Die werk bestaan uit twee hoofdele, waarvan Afdeling 1 'n teoretiese gedeelte en Afdeling 2 'n praktiese gedeelte is. Die eerste afdeling word gewy aan 'n basisteoretiese besinning oor aspekte van die dood. Van Niekerk beskryf onder andere die verskillende gesigte van die dood, sterwensdinamika, asook die dood in spirituele, psigiese en teologiese konteks. Afdeling 2 weer, word gewy aan praktiese aspekte in die begeleiding van sterwendes. Aspekte waaroor in hierdie afdeling nader besin word, is gesprekke met die sterwende, die mededeling van die waarheid oor die sterwende se toestand, etiese aspekte soos genadedood, die finale fase in die sterwensproses en ' $n$ besinning oor die lewe na die dood.

Wat positief beoordeel behoort te word, is die outeur se basisteoretiese verkenning van aspekte rondom sterwe en sterwensbegeleiding. Hy bied hieroor verrassende perspektiewe uit die Skrif.

'n Volgende positiewe aspek is dat hierdie boek, wetenskaplik gesproke, 'n populêr-wetenskaplike stuk navorsing is. Hoewel Van Niekerk nie noem by watter navorsingsmodel in die Praktiese Teologie hy aansluit nie, bied die geheel genoegsaam bewys dat die onderbou sterk praktiesteologies gerig is.

'n Finale inhoudelike opmerking - en miskien die belangrikste - is dat ons hier met 'n werk te doen het wat nie net aan die predikant as pastor leiding gee nie, maar ook rigtinggewende dimensies bied aan die verpleegster, die medikus en in besonder aan gelowiges oor hoe om sterwendes pastoraal te begelei, by te staan en te versorg. Die skrywer is goed geskool as dosent in Praktiese Teologie, maar ook as weermagkapelaan met die spesifieke opdrag om sterwendes in 'n oorlogsituasie pastoraal te begelei.

Tegnies is die werk goed en afgerond versorg. Ek beveel hierdie werk graag as rigtinggewende bron aan. 